\title{
CASE COMMENT ON ST. ANNE-NACKAWIC PULP \& PAPER CO. LTD. V. CANADIAN PAPERWORKERS UNION, LOCAL 219
}

\author{
ANDREW C.L. SIMS B.A., LL.B.*
}

For over 40 years, the Canadian system of labour relations has required that all disputes about the interpretation, application, or operation of a collective agreement be resolved by final and binding arbitration.' Notwithstanding this, courts have continued to assert a jurisdiction in areas arguably subject to arbitration. The recent Supreme Court of Canada decision in St. Anne-Nackawic Pulp \& Paper Co. Ltd. v. Canadian Paper Workers $^{2}$ goes a long way in clarifying previously grey areas of overlap between labour arbitration and the Courts. The decision comes down heavily in favour of arbitration while preserving a supporting role for the Courts sufficient to meet the most urgent situations requiring injunctive relief.

The most frequent judicial incursions into the areas governed by labour arbitration involve the wrongful dismissal action and the suit for an injunction and damages for an unlawful strike. The facts in St. AnneNackawic involve the latter, but the decision, as is shown by the recent decision of the Alberta Court of Appeal in Strthcona Steel Mfg. Inc. v. Oliva ${ }^{3}$ is of wider import. As well as withdrawing the Courts from a number of contentious areas of labour relations, it marks an important step in the Court's recognition of the overall scheme of our labour relations system. Since this scheme has been with us since the end of the Second World War, ${ }^{4}$ this belated recognition is most welcome.

The facts in St. Anne-Nackawic are relatively straightforward. The Union represented two bargaining units at the employer's pulp mill, one for the office workers and the other for the mill workers. The office workers went on a legal strike and set up picket lines. The mill worker's collective agreement in force contained a common no-strike provision, "There shall be no strike, lockout, stoppage, slowdown or restriction of output during the life of this Agreement". The mill workers honoured the office workers' picket line and stopped production at the plant. The employer then sought and obtained an interlocutory injunction from the Court directing the mill workers back to work. After a few days, and some contempt proceedings, the mill workers went back to work, although a further strike occurred a couple of weeks later. The office workers then settled and everybody went back to work.

* The author is the Chairman of the Alberta Labour Relations Board and a sessional instructor in law at the University of Alberta. The comments below are the author's personal observations and not made in any of ficial capacity.

1. While our labour relations are governed by diverse provincial and federal, and sometimes private versus public sector legislation, there is, to use George Adams' term a sufficient "common core" to justify a reference to the Canadian system. Virtually every labour act requires arbitration or some other dispute resolution method for intra-contract disputes. In Alberta the relevant provision is Labour Relations Act R.S.A. c. L 1.1 s. 118.

2. (1986) 28 D.L.R. (4th) 1 (S.C.C., Estey J.).

3. Unreported, 12 November 1986, 18881 (Alta. C.A.).

4. The first modern Canadian enactment was under the Wartime Labour Relations Regulations (P.C. 1003, proclaimed February 17, 1944). This regulation, which was the model for most post war provincial and federal legislation was an unabashed co-option of the key features of the Wagner Act, the American "new deal" labour legislation. 
The Company lost 18 days production as a result of the job action by the mill workers job action which cost an estimated $\$ 674,000$. It decided to pursue its action against the Union for this amount and issued a statement of claim alleging both a breach of the collective agreement term quoted above and a breach of the prohibition against untimely strikes in the New Brunswick Industrial Relations Act. ${ }^{3}$

On his own motion, Mr. Justice Higgins in the Trial Division of the New Brunswick Court of Queen's Bench asked the parties to address the question of whether the court had jurisdiction to entertain the action for damages given the existence of the collective agreement and its mandatory arbitration mechanism. ${ }^{6}$ As he put his concerns "I have gained the distinct impression during the last several years that the Supreme Court of Canada has clearly indicated that Courts should refrain from interference in matters of dispute arising out of a collective agreement - except on very limited grounds". This concern had been sparked by earlier Supreme Court cases including Shell Canada ${ }^{7}$ and Brunet. ${ }^{8}$

Higgins $\mathrm{J}$. dismissed the plaintiff's action on this preliminary motion, finding that the plaintiff had no right to avoid the collective agreement procedures by bringing the matter to Court. In his view the Industrial Relations Act as well as the contractual terms "supports and demands such an arbitration". It was this decision that eventually went to the Supreme Court of Canada.

How did the Courts tackle the question of whether they had jurisdiction to hear an action based on conduct that amounted to a breach of a term of a current collective agreement? I will first examine the general issue, and then the specific area of the wrongful dismissal action. The Courts' jurisdiction over mid-contract strikes was argued on three bases; that they could, notwithstanding the arbitration clause, entertain a claim for breach of the collective agreement; that they could entertain an action for breach of the statutory "no-strike" provision; and that they could entertain a claim on the basis of conspiracy or one of the economic torts. All three lines of argument were rejected because, in essence, the scheme of the Act assigned the job of adjudicating such disputes to arbitration. However, at the end of the day the Courts reserved to themselves the right to issue backto-work injunctions to preserve the integrity of the labour relations system.

Mr. Justice Estey begins his analysis by noting the requirements in the Act for a final and binding settlement mechanism for all disputes arising between parties to, or persons bound by, the collective agreement, concerning its interpretation, application, administration or alleged violation, backed up by a "model clause" that is deemed to apply if the parties fail to devise a comprehensive mechanism of their own. ${ }^{9}$ He then refers to the general rule; "the significant number of decisions doubting the

5. R.S.N.B. 1973, c. I-4, s. 91(1). For the equivalent Alberta provision see Labour Relations Act, R.S.A. 1980, c. L-1.1 as am. s. 105(1).

6. (1982) 131 D.L.R. (3d) 616 (N.B.Q.B.).

7. Shell Canada Ltd. v. United Oil Workers of Canada, Local I [1980] 2 S.C.R. 181, (1980) 114 D.L.R. (3d) 328.

8. General Motors of Canada Ltd. v. Brunet [1977] 2 S.C.R. 537, 77 C.L.L.C. 14,607.

9. Section 55 of the New Brunswick Act is in all material respects the same as ss. 118 and 120 of the Alberta act. 
jurisdiction of the Courts to hear claims based on the interpretation or application of the collective agreements containing provisions for binding arbitration", ${ }^{10}$ and then identifies two lines of cases that have been exceptions to the general exclusionary rule.

The exceptions focus on two cases that have always been difficult to reconcile with the mainstream of labour law: Hamilton Street Railway " and Woods v. Miramichi Hospital. ${ }^{12}$ The first exception is said to involve cases where the Courts are asked to enforce but not to interpret a fight in a collective agreement. The second exception consists of cases where the claim can be characterized as arising solely under the common law, and not under the collective agreement. The Supreme Court relied on Brunet ${ }^{13}$ and Shell Canada ${ }^{14}$ for the proposition "that there is no difference in principle between a dispute over the 'application' of a collective agreement and one relating to its "violation"" and held that "The jurisdiction of the Courts ought not, therefore, to depend on whether the parties dispute the meaning or application of the terms of the collective agreement". This apparently confines Hamilton Street Railway to the history books.

Miramichi Hospital met a similar fate when the Court said at p. 12, after discussing the role of arbitration in the overall labour relations scheme:

These considerations necessarily lead one to wonder whether the Miramichi case, supra, and cases like it, would survive an objection to the Court's jurisdiction if decided today.

After cutting off the two exceptions to the general rule the Court restated it with force, and without exception: ${ }^{15}$

From the foregoing authorities, it might be said, therefore, that the law has so evolved that it is appropriate to hold that the grievance and arbitration procedures provided for by the Act and embodied by legislative prescription in the terms of a collective agreement provide the exclusive recourse open to parties to the collective agreement for its enforcement.

This takes us to the second claim to jurisdiction, the action on the statute. The Court flatly rejected the suggestion that the no-strike prohibition in the Industrial Relations Act created a cause of action for damages in civil law. The Court saw the prohibition simply as part of the overall complex statutory labour relations scheme and felt it "hostile to the purpose and philosophy of such legislation to burden it with collateral actions in the courts for damages ..." This decision is hardly surprising given the Supreme Court's recent restrictive views on the creation of statutory torts. ${ }^{16}$

While the Court rejected the notion of a specific statutory right of action, as will be seen below, it is the overall scheme of the legislation that ultimately justified the Court's limited intervention by injunction. One could quibble over whether in the final analysis the Court has taken a tort

10. Supra n. 2 at p. 8.

11. Hamilton Street Railway Co. v. Northcott [1967] S.C.R. 3, (1966) 58 D.L.R. (2d) 708, 66 C.L.L.C. 599.

12. Woods v. Miramichi Hospital (1966) 59 D.L.R. (2d) 290 (N.B.S.C.A.D.).

13. Supra n. 8.

14. Supran.7.

15. Supra n. 2 at 14.

16. See, for example, Bhadauria v. The Board of Governors of Seneca College [1981] 2 S.C.R. 181 and $R$. v. Saskatchewan Wheat Pool [1983] 1 S.C.R. 205. 
jurisdiction with a limited remedy from the statute, or whether it has used inherent injunctive powers to support the statute whilst respecting the statutory intention to leave less urgent longer term adjudication to arbitration. However, in the writer's view the claim to jurisdiction, and its limits, is appropriate on policy grounds no matter which way it is characterized.

The third claim to jurisdiction was argued on the basis that acts that constitute a breach of the collective agreement can also constitute an actionable civil wrong. This aspect of the argument got no direct response from the Supreme Court of Canada, but was dealt with thoroughly by Mr. Justice La Forest, then sitting on the New Brunswick Court of Appeal." It was argued that the acts amounted to a conspiracy to injure or to breach the statute, or amounted to one of the other economic torts. The Court of Appeal said at p. 694:

For if the claim made in the present case is to be construed in terms of conspiracy, it is a conspiracy by the mill-workers to strike, which is the very thing that constitutes the "difference" for which the method of settlement is provided in the collective agreement. It seems to me that where the parties to a collective agreement agree to refer certain differences arising out of the agreement ... to final settlement by arbitration, such agreement should not be avoided by the simple device of framing the claim as a conspiracy. To do so would be to override the intention of the parties.

-..

Nor should the transparent device of saying that the acts also amount to a conspiracy or inducement to breach the individual contracts of employment be countenanced. These contracts must be looked at in the general context of collective bargaining.

While Mr. Justice Estey does not deal with this last assertion of jurisdiction, there is nothing in the judgment that expresses any disapproval of Mr. Justice La Forest's analysis, and the clear inference is that it is accepted. How then, having rejected these claims to any court jurisdiction, can the Court sustain a right to grant "back to work" injunctions, which is the net and express result of the decision?

The route by which the Court reaches this conclusion is difficult to describe, and one suspects this is deliberately so. The Court recognizes at $p$. 15 that granting an injunction just as much involves adjudicating over the collective agreement as does a damage claim. How can the Court sustain the one and deny that it has any jurisdiction over the other? Logically it cannot. What is offered instead are several very practical reasons why the jurisdiction over interim injunctions should be maintained. Firstly the Court observed at p. 14:

The history of labour law in our country since World War II reflects a rather straightforward pattern whereby the parties would take recourse to the superior courts by an action for injunction, declaration and damages in which an interlocutory or interim injunction was sought with a view to driving the other party back to the labour relations process presribed by statute. Rarely would the action proceed beyond the interlocutory injunction state.

What the Court is correctly pointing out is that while the interim injunction has a practical utility the rest of the action generally has very little. Secondly, the Court is faced with a number of clear decisions upholding the court's jurisdiction to grant such orders. ${ }^{18}$ Thirdly, the Court

17. (1982) 142 D.L.R. (3d) 678 (N.B.C.A.).

18. Supra n. 2 at 14 for a list of the cases. In particular see I.B.E.W. v. Winnipeg Builders Exchange [1967] S.C.R. 628. 
suggests it would be unfair to grant injunctions to employers without contracts while withholding the remedy from employers who had bargained contracts in compliance with the legislation. The Court goes on to suggest that the labour legislation does not unambiguously oust the court's jurisdiction, a proposition that would be easier to follow had it not been for the contrary argument a few pages earlier. This dialogue leads into the court's general injunctive power under the Judicature Act. The Court ultimately frames the assertion of jurisdiction not as a remedy for a breach of the collective agreement, nor for a breach of any specific statutory provision, nor as an aspect of any specific cause of action, but as a freestanding remedy designed to prevent an affront to the whole statutory scheme. The Court concludes at p. 20:

I therefore conclude that the courts do have a limited residual presence in the labour relations scheme as it has evolved in the legislative programme where the conduct amounts to a illegal strike or lock-out, and that the general jurisdiction to issue injunctions under the Judicature Act is unimpaired in this context.

Where does this leave the practitioner? Hitherto, the rule, at least as understood in Alberta, was that the Court would not grant as an interim injunction, a remedy that was in reality the whole of the plaintiff's claim. ${ }^{19}$ If the Court's jurisdiction is now limited to the grant of this interim injunction and no remedies are available beyond this initial order (and any ancillary contempt remedies that may be needed for enforcement) then the old rule has not only been revoked, but turned on its head.

Except for a passing reference to the old rule at p. 20 where the Court says "The court below does not appear ... to have taken the position that an otherwise competent court may not intervene by injunction alone" there is regrettably no clear statement on this point. However the result makes it clear enough. The Court can issue a back to work injunction and is without jurisdiction to award any other relief. Where formerly the interim injunction could not be the only relief sought it now must be the only relief sought. Little is lost since most statements of claim include a damage claim only to avoid the old rule. Something may be gained in that claims for damages sometimes inflame rather than soothe the job action it is sought to enjoin. What does need to be settled is whether one applies for an interim or permanent order, and how requirements such as the undertaking as to damages are to be dealt with.

One question the Court did not clearly address, in juxtaposing the labour arbitration against the injunction, is the jurisdiction of the labour relations boards. In some statutes (not Alberta's since the Court's jurisdiction over injunctions is implicitly preserved by s. 112) the jurisdiction over breaches of the Act, or at least over illegal strikes, falls within the exclusive jurisdiction of the Labour Relations Board. The same logic that drives Estey J. to uphold the exclusivity of arbitration might also drive the Court, in the one area of injunctions he sees as being left to the Court, to defer to the labour relations tribunal. Courts now on occasion defer to statutory remedies available before labour relations tribunals in cases where it appears that the tribunal is better suited to managing the situation

19. See: Shaughnessey Heights Property Owners Association v. Mc Andless [1942] 3 W. W.R. 504 and Board of Eston-Elrose School Unit No. 33 of Saskatchewan v. Saskatchewan Teachers Federation (1970) 75 W.W.R. 74. 
at hand. However at present this is usually a matter of discretion rather than jurisdiction.

Is a dismissed employee covered by a collective agreement still able to sue for wrongful dismissal? The answer now is "no". Alberta was one of the last holdouts in this area. For several years the brief unreported memorandum from the Court of Appeal bench in Gleed v. The City of Edmonton ${ }^{20}$ was the standard authority for the proposition that an employee, despite being covered by a collective agreement, and despite having failed to take advantage, in a timely way, of the grievance procedure in that agreement, could still bring an action in the ordinary courts for wrongful dismissal.

Gleed has now been specifically reversed by the Court of Appeal in the recent decision of Strathcona Steel Mfg. Inc. v. Oliva. ${ }^{21}$ The decision in Oliva was pending when St. Anne-Nackawic was handed down. The Court of Appeal found itself bound by the decision to find that the common law action for wrongful dismissal could not coexist with the arbitration remedy contained in the collective agreement. However, it is still worth looking at how Oliva was decided at the Queen's Bench level.

Whilst many practitioners doubted the reliability of Gleed in view of the substantial authority from courts elsewhere in Canada, it, along with Miramichi Hospital, ${ }^{22}$ was a sufficient worry to make grievance settlements difficult to negotiate, for fear that an employer, released by the Union, might still be faced with a suit by the individual employee should that employee be unwilling to accept the settlement negotiated by the Union. These fears proved to be well founded with the Queen's Bench decision in Oliva. ${ }^{23}$ That decision, now reversed, involved a refusal on a preliminary motion to dismiss a wrongful dismissal action brought by an employee covered by a collective agreement.

Oliva, at the Queen's Bench level, canvassed the most eloquent of the leading authorities that argue that the law of collective bargaining should not be interpreted to "deprive workers of all their common law rights", but ultimately relied upon the authority of Gleed. With respect, these cases overstated the point. A dismissed employee at common law has a right to a wrongful dismissal action. This, at best, may yield a modest damage award, usually made more modest by the costs of litigation. The common law gave no power of reinstatement. Most collective agreements give employees the right to grieve their dismissal and obtain the more useful remedy of reinstatement. ${ }^{24}$ However, the grievance procedure itself is usually a product of collective bargaining. Employers pay good money in the bargaining process for short and definite limitation periods. In addition, unions rather than affected employees usually, but not universally, have control over whether a case proceeds to arbitration, is settled or is abandoned.

20. Unreported memorandum from the bench dated January 6 th 1981.

21. Supran. 3.

22. Supra n. 12.

23. [1985] 1 W.W.R. 610 (Alta. Q.B.).

24. The right to grievance arbitration for dismissal is not universal, and the position of the probationary employee, often excluded from the right to grieve, is a matter of some controversy. The Labour Relations Act s. 125(2) and similar legislation elsewhere adds a remedial jurisdiction to an arbitrator's powers in cases of discharge and discipline. 
It is this last feature that underlies most of the judicial reluctance to hold that the collective bargaining regime replaces the wrongful dismissal action. This same concern prompted Mr. Justice Stevenson in separate but concurring reasons in the Court of Appeal decision in Oliva to call for some legislative attention in this area. Surely, it is argued, employees must have some action they can bring on their own if they cannot get their union's support? The answer the labour relations scheme provides for this is the duty of fair representation imposed by law upon unions. ${ }^{25}$ However this answer is usually overlooked or considered to be too collectivist to overcome the objections of individualists.

It is the writer's experience over many years of wrongful dismissal and arbitration practice that the unionized employee with the right to grieve and the right to fair representation is in a lot better legal position than the dismissed "common law employee" with a right to a few weeks wages when, and if, lack of just cause can be proven in the courts. In many cases the employer is also better off because of the certainty given by the time limits in the grievance procedure. Cases like Gleed really give the employee the penny and the bun, and unjustifiably deprive the employer of the benefit of the "deemed abandonment" clause usually negotiated as part of the grievance procedure.

As Strathcona Steel v. Oliva shows, St. Anne-Nackawic has sounded the death knell for the wrongful dismissal action for an employee covered by a current collective agreement. A strong note of caution to practitioners is therefore in order. Anyone advising a client who has been dismissed from employment must be sure to find out immediately whether that person is or is not covered by a collective agreement. The time limits for filing grievances can sometimes be as short as a few days. The residual ability to bring a common law wrongful dismissal action was too often a fortuitous safety net for practitioners who had missed the time limit for filing a grievance under the applicable collective agreement.

St. Anne-Nackawic is important because it is the most forceful statement the Supreme Court of Canada has made, in the forty plus years it has had to review our labour legislation, in recognition of the "comprehensive scheme" or "code" nature of Canadian labour relations statutes. During World War II Canada adopted the basic scheme for labour relations embodied in the American Wagner Act. This piece of New Deal legislation deliberately established a regulatory scheme that would be run by expeditious specialists without undue intervention by the [implicitly too conservative] Courts. That the resultant process has proven slower than hoped for, and some Courts less conservative than feared, does not change the basic approach in the statutes.

The Court goes a fair distance in recognizing this scheme, although, as noted above, one important element in the overall scheme, the labour relations board, is given ony the briefest mention. The Court says at p. 11:

25. The duty of fair representation in Alberta is imposed by s. 138(i) of the Labour Relations Act. The Supreme Court has given a relatively recent judgment on the duty in Gagnon v. Canadian Merchant Service Guild [1984] C.L.L.C. 14,043 (S.C.C.). Some jurisdictions do allow the Labour Relations Board to relieve against time limits in a collective agreement when the duty of fair representation has been breached. 
The Legislature created the status of the parties in a process founded upon a solution to labour relations in a wholly new and statutory framework at the center of which stands a new forum, the contract arbitration tribunal. Furthermore, the structure embodies a new form of triangular contract with but two signatories, a statutory solution to the disability of the common law in the field of third party rights. These are but some of the components in the all-embracing legislative programme for the establishment and furtherance of labour relations in the interest of the community at large as well as in the interests of the parties to those labour relations.

This recognition is bolstered at page 12, when the Court, in addressing whether the legislature intended arbitration to be a basically exclusive remedy, said:

The more modern approach is to consider that labour relations legislation provides a code governing all aspects of labour relations, and that it would offend the legislative scheme to permit the parties to a collective agreement, or the employees on whose behalf it was negotiated, to have recourse to the ordinary courts which are in the circumstances a duplicative forum to which the Legislature has not assigned these tasks.

The only surprising thing in these statements is the fact that these fairly basic features of the scheme of the Acts have taken forty-two years to be recognized by the Courts in any substantial way. After all, there have been virtually no substantial modifications to the basic scheme of the Acts since they were first introduced. Certainly there have been very few basic changes to the concept of collective agreement arbitration which seems to be the key feature behind this decision.

Admittedly, this is not the first indication that the Supreme Court recognizes the "comprehensive scheme" of the Labour Relations Acts; McGavin Toastmaster ${ }^{26}$ contains the same notion, and the whole thrust of the "patently unreasonable" test for judicial review is based on the same proposition; however, this is by a long chalk the most direct and explicit recognition. It comes just as the Wagner Act is celebrating its 50th anniversary.

Mr. Justice Estey's judgment is all the more important because of the formidable array of cases to cut through in order to establish the integrity of the statutory labour relations scheme. While courts have not been reluctant to assume a substantial, if inconsistent, role in the labour relations process, counsel have on occasion been equally reluctant to accept this overall social scheme approach. In this case, and several others, it was the Court, not counsel, that took the lead in suggesting the Court was without jurisdiction. Chief Justice Laskin indicated a willingness to adopt the same approach in McGavin Toastmaster as early as $1975^{27}$

Perhaps this very gradual process of acceptance of collective bargaining law as something more than "common law contracts in bulk" is an inevitable result of history. The Wagner Act was a key part of the American New Deal package. It came in at a time of major social change and was avowedly "different". The Canadian law was ushered in by regulation, as a war measure while the national concern was focused elsewhere, and was borrowed rather than being forged out of a nationwide Canadian debate.

It should be emphasized that St. Anne-Nackawic deals with labour relations while a collective agreement is in force. Many of the more difficult jurisprudential problems in labour relations concern pre or post-

26. McGavin Toastmaster Ltd. v. Ainscough [1976] I S.C.R. 718.

27. Id. 
contract relationships. This limitation on the reach of the case has already been recognized in Alberta in Mr. Justice Mason's judgment in Burns Meats. ${ }^{28}$

The decision centers on the thesis that disputes over a collective agreement should be settled by arbitration. This is healthy, because the presence of unresolved litigation in the Courts over damages, which take a long time to resolve, provide an undesirable restraint on the collective bargaining process. The result of this decision is not a loss of rights but a change in forum. The available remedies in this different forum may however be different. The Court says at p. 21 "This appeal does not require comment upon the question of the range of remedies the board may apply in disposing of differences arising under the collective agreement . ." although it hinted at page 20 ". . . if arbitration is pursued, the remedies may be damages or reinstatement, or other remedial procedures known to labour law". Arbitration at least provides the opportunity for arbitrators to devise, as labour relations boards have done, remedial solutions that, even though novel, may suit the labour relations realities of the parties..$^{29}$ This forceful judgment in favour of the exclusivity of the arbitration remedy is a strong argument against the suggestion, in Smoky River Coal, that arbitrators cannot apply the law of equity. ${ }^{30}$

This decision is a bold one that clears up a number of inconsistencies in the law of labour relations. A number of troublesome cases have been reconsidered and overruled, albeit gently. The ultimate decision to limit the Court's role in collective agreement based disputes to an emergency support role is ultimately a policy decision. This can be seen from the following extract from p. 20:

The learned author [George W. Adams Q.C.] goes on to say that the courts will decline intervention where 'equally effective' remedies are available elsewhere. The lack of such remedies in the reality of an expensive stoppage of production is indeed the prime reason for the continued availability in the law of the judicial remedy of injunction, at least in the case of illegal strikes.

Result oriented or not, the decision is a most helpful addition to, and updating of, the Canadian jurisprudence on labour relations.

28. Tod Noa v. Burns Meats Ltd. unreported, 16 September 1986 (Alta. Q.B.). However, there are situations where an arbitration clause might be implied into a post contract common law contract of employment, in which at least some of the arguments in St. Anne-Nackawic might remain relevant. See: Ricafort v. Mental Health Hospital, Edmonton unreported, 16 May 1986 (Alta. C.A.).

29. For example, compensation for an illegal strike has been given by ordering unpaid overtime equivalent to the time lost through the illegal shutdown.

30. Smoky River Coal Ltd. v. United Steelworkers of American Local 7621 (1984) 8 D.L.R. (4th) 603, 31 Alta. L.R. (2d) 269, (Q.B.); affd. on other grounds (1985) 38 Alta. L.R. (2d) 193 (C.A.). The Court of Appeal doubted, but did not reverse, the Queen's Bench decision on the question of an arbitrator's entitlement to apply equitable principles. 